Article

\title{
Climate Warming and Drought in the Bialowieza Forest from 1950-2015 and Their Impact on the Dieback of Norway Spruce Stands
}

\author{
Andrzej Boczoń ${ }^{1, *(\mathbb{D})}$, Anna Kowalska ${ }^{1}$, Marek Ksepko ${ }^{2}$ and Karol Sokołowski ${ }^{1}$ \\ 1 Forest Research Institute, ul. Braci Leśnej 3, 05-090 Sękocin Stary, Poland; a.kowalska@ibles.waw.pl (A.K.); \\ k.sokolowski@ibles.waw.pl (K.S.) \\ 2 Bureau for Forest Management and Geodesy, ul. Lipowa 51, 15-424 Białystok, Poland; \\ marek.ksepko@bialystok.buligl.pl \\ * Correspondence: a.boczon@ibles.waw.pl; Tel.: +48-22-7150534
}

Received: 6 August 2018; Accepted: 16 October 2018; Published: 23 October 2018

check for updates

\begin{abstract}
The Bialowieza Primeval Forest (BF) is one of the well-known forests in Central Europe. The most common tree species in BF was Norway spruce (Picea abies (L.) H. Karst), comprising $26 \%$. However, a mass dieback of spruce has occurred during recent years. The spruce dieback in Bialowieza Forest is directly caused by the spruce bark beetle. However, the mass appearance of this pest can be a consequence of global warming and drought. Changes in air temperature were presented and drought indices were calculated as follows: standardized precipitation index, Palmer drought severity index, climatic water balance and soil water storage deficit. The warming of the climate of Bialowieza from 1950 to 2015 is comparable to that observed throughout central Europe. The temperature increased by $1.27^{\circ} \mathrm{C}$. The occurrence of drought from 1950 to 1966 and from 1985 to 2015 had a similar frequency. From 1963 to 1966, the volume of removed deadwood from the managed part of Bialowieza Forest was 27 thousand $\mathrm{m}^{3}$ but from 2012 to 2016, the volume was more than one million $\mathrm{m}^{3}$.
\end{abstract}

Keywords: Bialowieza Forest; climate change; drought; drought indices; Norway spruce

\section{Introduction}

The occurrence of long, rainless periods (over 28 days) in 1997 and 2000 in Bialowieza Forest was previously indicated by [1] and the drought in 2000 caused a significant reduction in the groundwater level [2], which could have posed a serious threat to tree health. Soil drought occurred over large areas of Poland in 2015 [3].

A spruce bark beetle outbreak has recently caused a massive dieback of spruce in the Bialowieza Forest [4]. The outbreak has further expanded since 2012, resulting in hundreds of thousands of standing dead trees [4] both in the managed forests and in the Bialowieza National Park (BNP).

The spruce dieback in Bialowieza Forest is directly attributed to the spruce bark beetle [5]. However, the mass appearance of this pest is often a consequence of global warming [6]. Therefore, the question arises whether the climate of Bialowieza Forest has warmed up, influencing habitat conditions that caused the spruces to weaken, thereby increasing their susceptibility to attack by the spruce bark beetle in recent years. Norway spruce is a boreal species; thus, it is cold-adapted but drought-sensitive $[7,8]$. This species is highly vulnerable to the increasing frequency and severity of drought events associated with recent climate change [9]. These traits make it particularly vulnerable to projected climate changes in central Europe [10]. Allen et al. [11], as well as Birdsey and Pan [12], observed an increase in tree mortality as a consequence of drought and warm temperature in forests. 
The aim of this study is to determine the occurrence of global warming and drought stress in the period from 1950 to 2015 in the Bialowieza Primeval Forest and an attempt to find a connection between droughts and spruce dieback.

\section{Materials and Methods}

Bialowieza Forest is located on the border between Poland and Belarus $\left(52^{\circ} 45^{\prime} 29^{\prime \prime} \mathrm{N} ; 2^{\circ} 46^{\prime} 8^{\prime \prime} \mathrm{E}\right)$. Its area is $1345 \mathrm{~km}^{2}$, of which $592 \mathrm{~km}^{2}$ is in Poland and $753 \mathrm{~km}^{2}$ in Belarus. The Bialowieza Forest reserve is one of the last and largest fragments of original European lowland forest. For the most part, Bialowieza Forest is composed of multi-species stands. A total of 4693.24 ha of the forest was designated Bialowieza National Park (BNP) in 1932, one of the first national parks in Europe. Today, BNP encompasses an area of 10,517.27 ha, of which 6059.27 ha is under strict protection. The remaining area of Bialowieza Forest is managed forest but this part also has nature preserves and sites with protected tree stands, habitats and species (Figure 1).

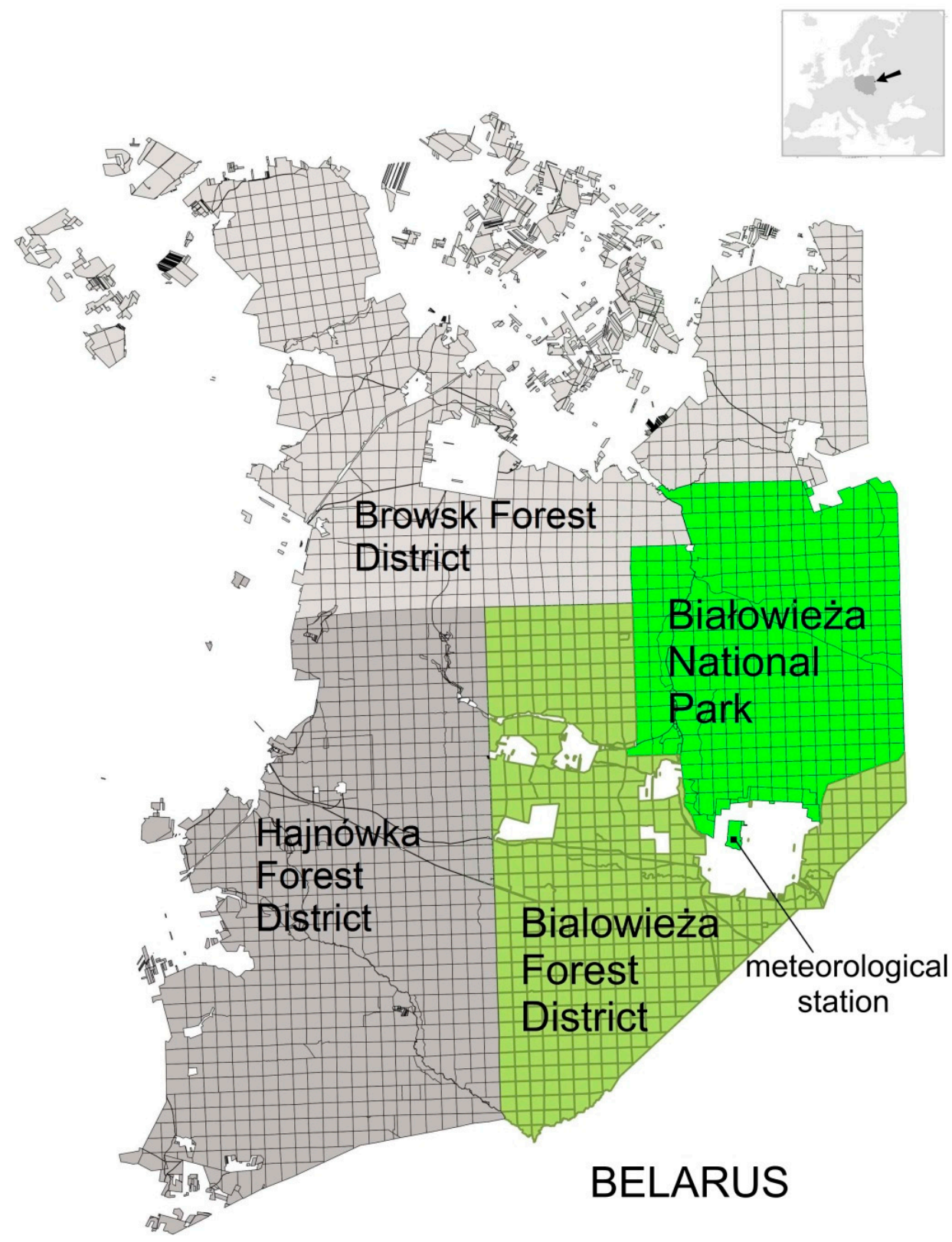

Figure 1. Polish portion of Bialowieza Forest. Grids denote the borders of forest subcompartments. 
In 1977, The United Nations Educational, Scientific and Cultural Organization (UNESCO, Paris, France) designated Bialowieza National Park as a world Biosphere Reserve and in 2005, the area of the Biosphere Reserve was expanded to include the entire Polish part of Bialowieza Forest. In 2014, all of Bialowieza Forest (Polish and Byelorussian sites) became a UNESCO World Heritage Site.

Spruce is one of the main species constituting the tree stands of Bialowieza Forest. Coniferous and mixed coniferous stands account for $52 \%$ of the total area, wet broadleaved forests $20 \%$, rich mesic broadleaved forests $15 \%$ and successional stands $13 \%$. The most common tree species are Norway spruce (Picea abies (L.) H. Karst.) —26\%, Scots pine (Pinus sylvestris L.) -24\%, black alder (Alnus glutinosa (L.) Gaertn.) -17\%, pedunculated (Quercus robur L.) and sessile (Q. petraea (Matt.) Liebl.) oaks-12\% and birch (Betula sp.) - $11 \%$. Nearly $40 \%$ of Bialowieza Forest is covered by stands over 80 years old [13].

\subsection{Meteorological Data}

Climate change and drought indices were determined on the basis of meteorological data from the Bialowieza station located at $52^{\circ} 42^{\prime} 25.7^{\prime \prime} \mathrm{N}, 23^{\circ} 50^{\prime} 52.2^{\prime \prime} \mathrm{E}$ at an elevation of $163 \mathrm{~m}$ above sea level. Meteorological measurements began to be recorded by the Forest Research Institute following the Second World War and they were continued by the Institute of Meteorology and Water Management from the mid-1960s to today. Measurements are taken three times per day. The study used the results of temperature and relative humidity measurements at a height of $2 \mathrm{~m}$ and atmospheric precipitation. Solar radiation measurements are not carried out at the station.

The trend of air temperature changes from 1950 to 2015 was verified by the Mann-Kendall test and Sen's slope estimates using the Makesens 1.0 software developed by the Finnish Meteorological Institute (Helsinki, Finland) [14].

The Mann-Kendall test is calculated for more of 10 data values using the formula:

$$
Z= \begin{cases}\frac{S-1}{\sqrt{\operatorname{VAR}(S)}} & \text { if } S>0 \\ 0 & \text { if } S=0 \\ \frac{S+1}{\sqrt{\operatorname{VAR}(S)}} & \text { if } S>0\end{cases}
$$

where $S$-Kendall's statistic with expectation zero and variance $\operatorname{VAR}(S)$ :

$$
\operatorname{VAR}(S)=\frac{1}{18}\left[n(n-1)(2 n+5)-\sum_{p-1}^{q} t_{p}\left(t_{p}-1\right)\left(2 t_{p}+5\right)\right]
$$

q-the number of tied groups

$t_{p}$ - the number of data values in the $p$ th group.

$$
S=\sum_{k=1}^{n-1} \sum_{j=k+1}^{n} \operatorname{sgn}\left(x_{j}-x_{k}\right)
$$

To estimate the true slope of an existing trend (as change per year) the Sen's nonparametric method is used. The Sen's method can be used in cases where the trend can be assumed to be linear. This means that $f(t)$ in equation is equal to

$$
f(t)=Q t+B
$$

where

$Q$ - the slope

$B$-a constant. 
The Sen's estimator of slope is the median of $N$ values of $Q_{i}$. The $N$ values of $Q_{i}$ are ranked from the smallest to the largest and the Sen's estimator is:

$$
\begin{gathered}
Q=Q_{[(N+1) / 2]}, \text { if } N \text { is odd } \\
Q=0.5\left(Q_{[N / 2]}+Q_{[(N+2) / 2]}\right), \text { if } N \text { is even }
\end{gathered}
$$

To obtain an estimate of $B$ the $n$ values of differences $x_{i}-Q t_{i}$ are calculated. The median of these values gives an estimate of $B$.

\subsection{Drought Indices}

The occurrence of drought was determined by using the four indicators (Standardized Precipitation Index, Palmer Drought Severity Index, Climatic Water Balance, Palmer, Soil Water Storage Deficit) described below. The calculations were carried out for full years in monthly periods. The analysis of the results focused on the growth period of spruces as follows: May, June and July, when trees increase markedly in thickness (based on own research on the continuous high-resolution tree growth carried out on the forest monitoring plots of ICP-Forests program). The occurrence of drought was considered reliable when at least two calculated drought indicators of moderate, severe, or extreme intensity were found during the same period.

\subsubsection{Standardized Precipitation Index-SPI}

SPI calculations are based on fitting a gamma probability density function to a given frequency distribution of precipitation for a climate station. The cumulative probability is transformed to the standard normal random variable with mean zero and variance of one, which is the value of the SPI:

$$
\begin{gathered}
\mathrm{SPI}=-\left(t-\frac{c_{0}+c_{1} t+c_{2} t^{2}}{1+d_{1} t+d_{2} t^{2}+d_{3} t^{3}}\right), t=\sqrt{\ln \left(\frac{1}{(H(x))^{2}}\right)}, \text { for } 0<H(x) \leq 0.5 \\
\mathrm{SPI}=t-\frac{c_{0}+c_{1} t+c_{2} t^{2}}{1+d_{1} t+d_{2} t^{2}+d_{3} t^{3}}, t=\sqrt{\ln \left(\frac{1}{(1.0-H(x))^{2}}\right)}, \text { for } 0.5<H(x) \leq 1.0
\end{gathered}
$$

$H(x)$-cumulative probability.

Categories of drought intensity were determined depending on the standardized precipitation index (SPI) [15] values proposed for Poland's climatic conditions [16]:

$-0.50<$ SPI $<-1.49-$ Moderate drought

$-1.50<$ SPI $<-1.99-$ Severe drought

$\mathrm{SPI} \leq-2.00-$ Extreme drought.

The time windows used for the present study are 1-month and 12-month. The SPI was calculated for each year and months, Monthly calculations are presented for months of spruce growth: May, June, July.

\subsubsection{Palmer Drought Severity Index (PDSI)}

PDSI was calculated using the PDSI ver. 2 software developed by the National Agricultural Decision Support System, University of Nebraska-Lincoln (Lincoln, NE, USA). PDSI are calculated on the basis of precipitation and temperature data of the actual and preceding periods, as well as the available soil moisture content. The original classification of meteorological drought was applied using the PDSI [17]: 
$0.49<$ PDSI $<-0.49-$ Near normal

$-0.50<$ PDSI $<-0.99$ - Incipient drought

$-1.00<$ PDSI $<-1.99-$ Mild drought

$-2.00<$ PDSI $<-2.99-$ Moderate drought

$-3.00<$ PDSI $<-3.99-$ Severe drought

PDSI $<-4.00$-Extreme drought.

The PDSI was calculated for each month from 1950 to 2015.

\subsubsection{Climatic Water Balance (CWB)}

Climatic water balance is the difference between precipitation and evapotranspiration $(\mathrm{P}-\mathrm{EVT})$. The indicator was calculated for months and years based on the evapotranspiration calculated using the Ivanov formula:

$$
E V T_{m}=0.0018 \cdot(25+T)^{2} \cdot(100-R H)
$$

$E V T_{m}$ - evapotranspiration after Ivanov (mm month ${ }^{-1}$ )

$T$-monthly average air temperature $\left({ }^{\circ} \mathrm{C}\right)$

RH-monthly average air humidity (\%).

Drought intensity criteria were adopted as follows:

$0 \mathrm{~mm}<\mathrm{CWB}<-49.9 \mathrm{~mm}-$ Moderate drought

$-50 \mathrm{~mm}<\mathrm{CWB}<-99.9 \mathrm{~mm}$-Severe drought

CWB $>-100 \mathrm{~mm}-$ Extreme drought.

The calculations were performed for two periods, first—from 1950 to1966 and second-from 1985 to 2015. This is because relative humidity data was unavailable for period between 1967 and 1984 . Earlier publications indicate that there was low precipitation in Bialowieza during these periods, while the precipitation was much higher from 1967 to 1984 -average annual precipitation $708 \mathrm{~mm}$ [1,18] (Figure 2). The negative effects of drought stress on spruce were expected in periods with lower precipitation (1950-1966 with average precipitation $573 \mathrm{~mm}$ and 1985-2015 with average precipitation $625 \mathrm{~mm})$.

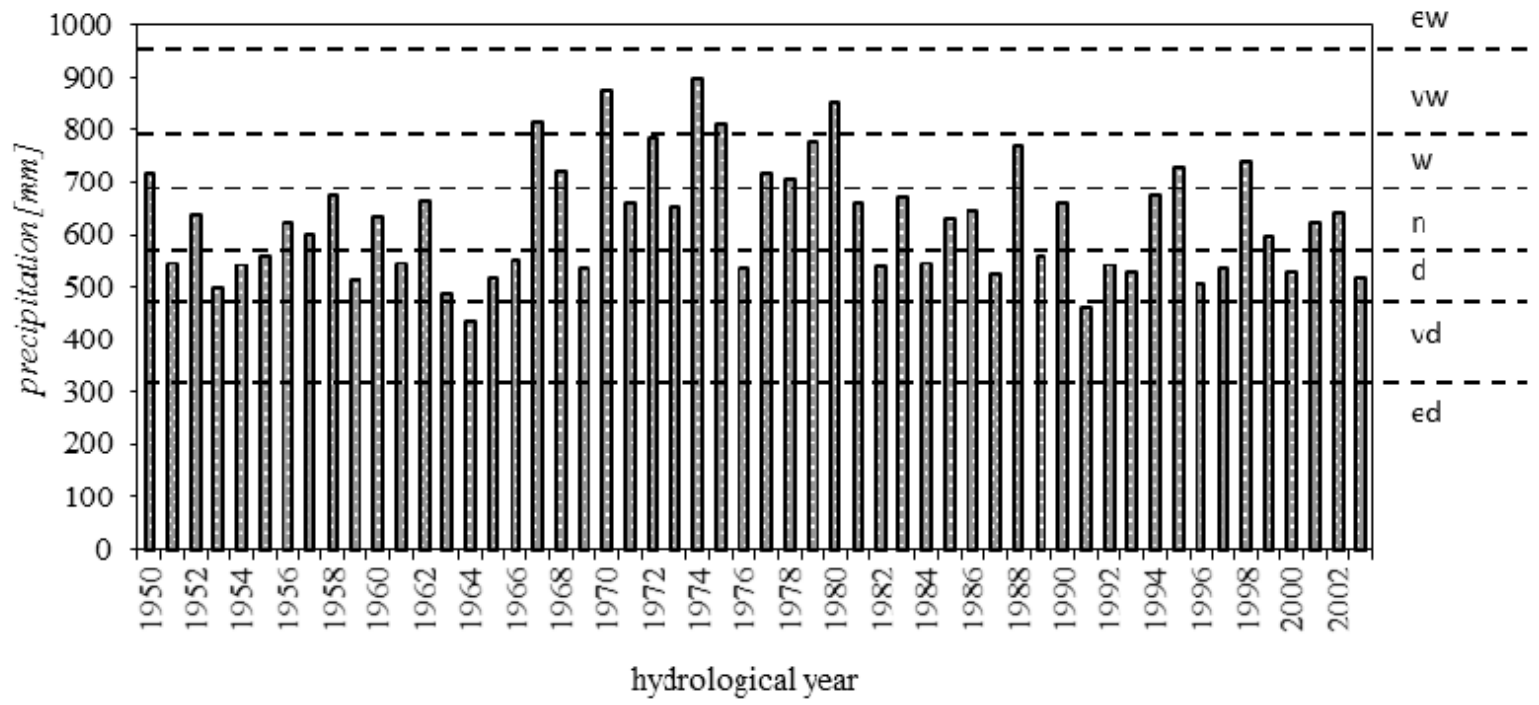

Figure 2. Precipitation in Bialowieza in the period 1950-2003 for hydrological year, (ew-extremely wet, vw—very wet, w—wet, n—normal, d—dry, vd—very dry, ed—extremely dry) [1]. 


\subsubsection{Soil Water Storage Deficit (SWSDef.)}

Soil water storage (SWS) is the total amount of water that is stored in the soil reservoir. SWS was calculated for each day, based on the balance of water outflow in the process of evapotranspiration and inflow of water from atmospheric precipitation using the following formula:

$$
\mathrm{SWS}_{(i+1)}=\mathrm{SWS}_{i}+T F_{i}-E V T_{i}
$$

SWS-soil water storage (mm),

$i-$ day number,

EVT-daily evapotranspiration ( $\mathrm{mm})$,

TF-throughfall (mm),

$$
T F=P-I
$$

$P$-daily precipitation ( $\mathrm{mm})$,

I-daily interception ( $\mathrm{mm})$.

Evapotranspiration was calculated using the Ivanov formula [19] as follows:

$$
E V T_{d}=0.000036 \cdot(25+T)^{2} \cdot(100-R H)
$$

$E V T_{d}$-evapotranspiration after Ivanov $\left(\mathrm{mm} \mathrm{day}^{-1}\right)$,

$T$-daily average air temperature $\left({ }^{\circ} \mathrm{C}\right)$

$\mathrm{RH}$-daily average air humidity (\%).

Interception $(I)$ was calculated with the Liu model [20,21]. The canopy water storage was determined using the Kondo model [22,23]

The determination of drought was based on the availability of soil water for plants. The moment of drought stress was determined as the limit of water availability for plants, occurring at soil water potential $(\mathrm{SWP}) \geq-0.5 \mathrm{MPa}$. The calculations were carried out with the following boundary conditions:

1. SWS at SWP $=-0.01 \mathrm{MPa}$ - the upper limit of the amount of water that can be retained in the soil to a depth of $60 \mathrm{~cm}$, above this value, water flows out of the profile.

2. SWS at SWP $=-1.5 \mathrm{MPa}$ - the lower limit of the amount of water that can be found in the soil to a depth of $60 \mathrm{~cm}$ under natural conditions.

The following ecosystem characteristics of a spruce stand were used in the calculations:

- leaf area index and the ground cover of a spruce stand were determined based on hemispheric photographs and HemiView software version 2.1 SR1 (Delta-T Devices Ltd., Burwell, Cambridge, UK);

- type of soil-Eutric Cambisols-40\% of spruce tree stands in Bialowieza Forest grow in a mixed broadleaved-coniferous forest under fresh soil moisture regime and $63 \%$ of this habitat is developed on Eutric Cambisols;

- $\quad \mathrm{pF}$ curve-the curve of water retention of Eutric Cambisol soil was determined in the laboratory. Based on the $\mathrm{pF}$ curve, the boundary values of soil water storage to a depth of $60 \mathrm{~cm}$ were calculated as follows: at SWP $=-0.01 \mathrm{MPa}$-field capacity (FC) SWS $=169.5 \mathrm{~mm}$; at SWP $=-0.5 \mathrm{MPa}$-early wilting point $(\mathrm{EWP}) \mathrm{SWS}=95.8 \mathrm{~mm}$; and at $\mathrm{SWP}=-1.5 \mathrm{MPa}-$ permanent wilting point $(\mathrm{PWP}) \mathrm{SWS}=86.6 \mathrm{~mm}$. A 60-cm depth was chosen due to the depth of the spruce's root system and the level of capillary rise in the soil. Spruce has a shallow root system, reaching a depth of approximately $40 \mathrm{~cm}$ in the soil [24].

The SWS was calculated for each day of the periods from 1950 to 1966 and from 1985 to 2015 (for the same reason as CWB). 


\subsection{Volume of Wood Cut}

The volume of cut wood in sanitary cuts is evidence of the intensity of tree dieback. Information on the amount of timber harvested as part of sanitation cutting was obtained from the area of Bialowieza Forest District for the years 2002-2017. In 1992, spruce stands occupied in this forest district $31 \%$ of the forest area, of which $85 \%$ were tree stands over 60 years of age.

Sanitation felling are executed in order to remove the trees attacked by insects or diseases and to prevent the pests from spreading.

Relations between drought indices and volume of wood cut were carried out by differentiating the intensity of drought and the assumption that the water deficit effect became apparent in 1 and 2 years after the drought.

Differences in median volume of wood cut in first and second year after the drought between the levels (0-3) of the intensity of drought for four drought indicators (SPI, PDSI, CWB and SWSDef) were tested using the Kruskal-Wallis non-parametric one-way analysis of variance. Calculation was performed in R environment [25].

\section{Results}

\subsection{Air Temperature}

The average temperature in Bialowieza from 1950 to 2015 was $6.9^{\circ} \mathrm{C}$. During this period, there was a clear and according to Mann-Kendall test significant increase in temperature by $1.27^{\circ} \mathrm{C}$. A significant temperature increase, by $1.26{ }^{\circ} \mathrm{C}$, occurred during the spruce growth period (May-July) (Table 1). Trend slope also showed an increase in the daily maximum temperature, while the daily minimum temperature was stable (Table 1, Figure 3).

Table 1. Seasonal Mann-Kendall test statistics for time series of air temperature in Bialowieza.

\begin{tabular}{|c|c|c|c|c|}
\hline \multirow{2}{*}{ Name } & \multicolumn{4}{|c|}{ Air Temperature $\left({ }^{\circ} \mathrm{C}\right)$} \\
\hline & Annual Average & May-July Average & Minimum Annual & Maximum Annual \\
\hline Years & \multicolumn{4}{|c|}{$1950-2015$} \\
\hline $\mathrm{n}$ & 66 & 66 & 66 & 66 \\
\hline Test $Z$ & 3.86 & 2.85 & -0.09 & 2.06 \\
\hline Significance ${ }^{(1)}$ & $* * *$ & $* *$ & n.s. & * \\
\hline $\begin{array}{c}\text { Sen's estimate for } \\
\text { temperature difference } \\
\text { between } 2015 \text { and } 1950\left({ }^{\circ} \mathrm{C}\right)\end{array}$ & 1.27 & 1.26 & -0.2 & 1.37 \\
\hline
\end{tabular}

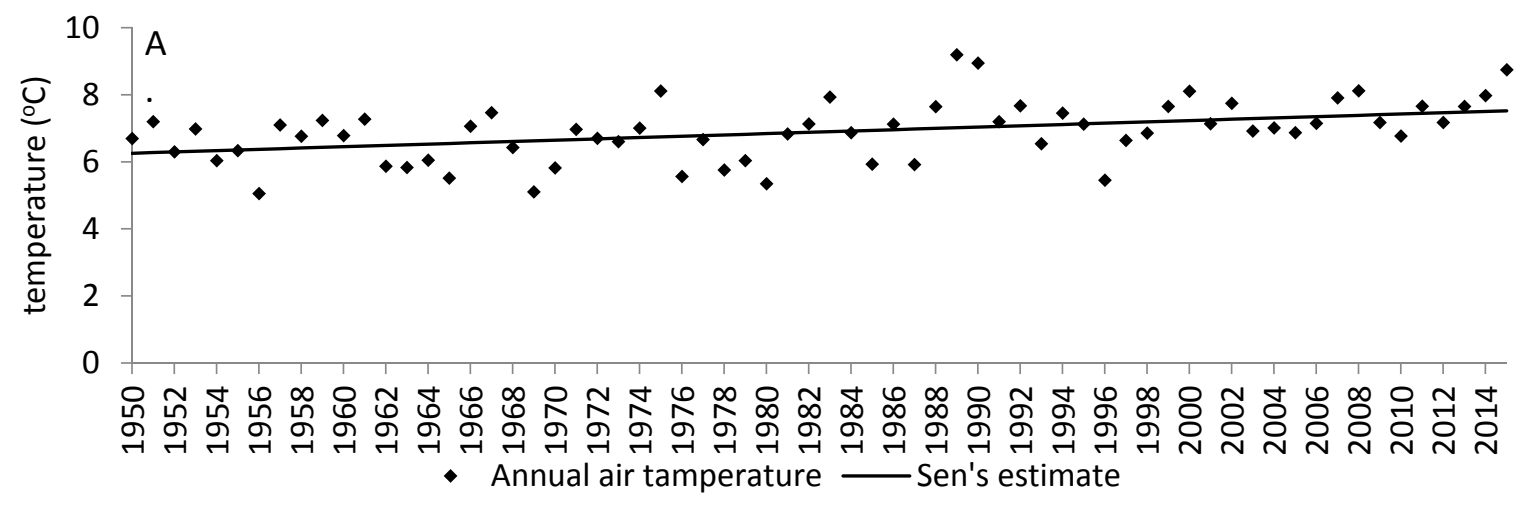

Figure 3. Cont. 

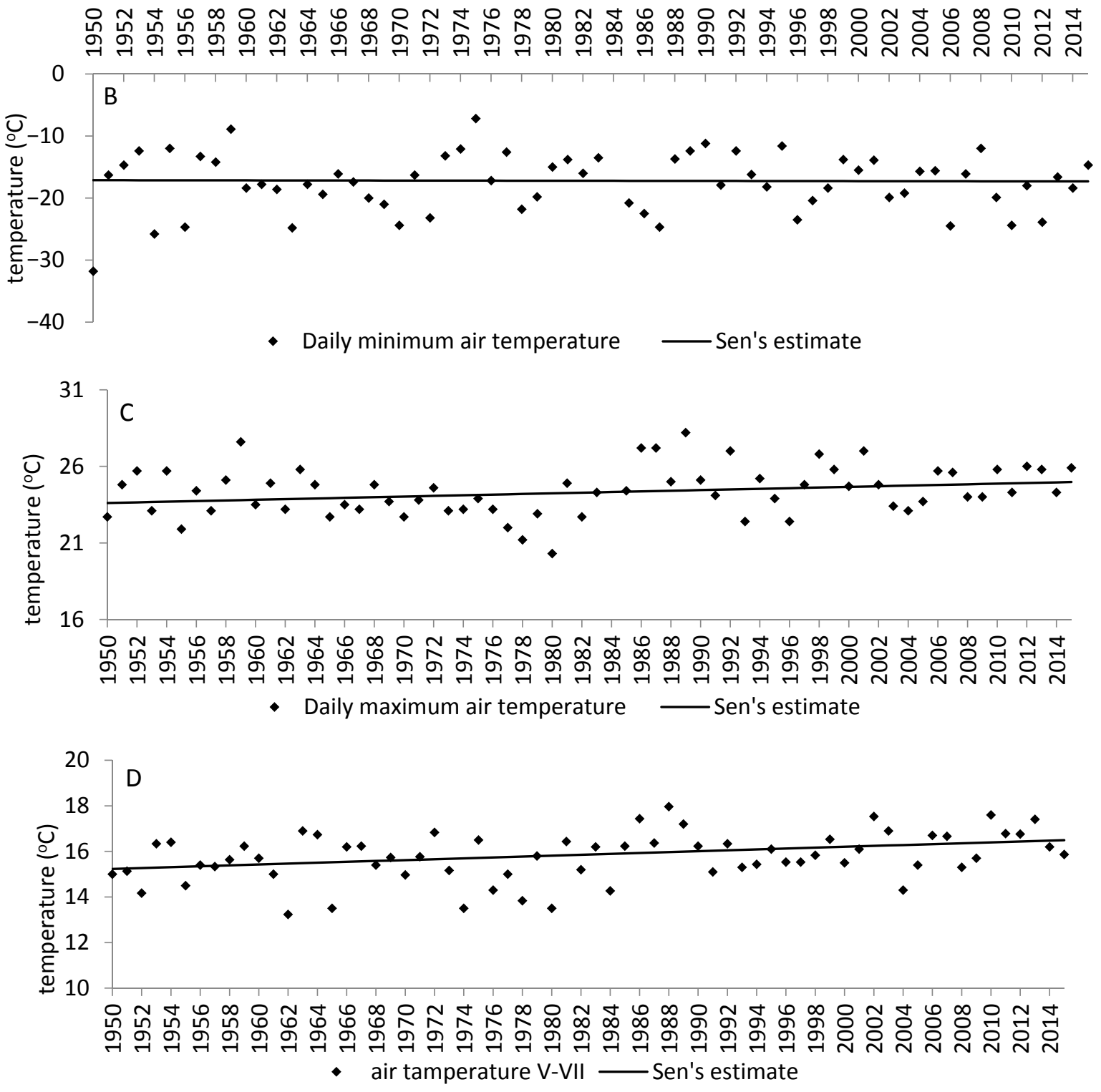

Figure 3. Annual average (A); daily minimum (B); daily maximum (C); average from May to July (D). Air temperature from 1950 to 2015 in Bialowieza.

During the periods of low precipitation from 1950 to 1966 (period I) and from 1985 to 2015 (period II), the average annual temperature was $6.5^{\circ} \mathrm{C}$ (range from $5.05{ }^{\circ} \mathrm{C}$ to $7.3{ }^{\circ} \mathrm{C}$ ) and $7.3{ }^{\circ} \mathrm{C}$ (range from $5.9^{\circ} \mathrm{C}$ to $9.2^{\circ} \mathrm{C}$ ), respectively. Since 1997, the average annual air temperature has not been below $6.6^{\circ} \mathrm{C}$.

The average air temperature between May and July in period I was $15.4{ }^{\circ} \mathrm{C}$ (range from $13.2^{\circ} \mathrm{C}$ to $16.9^{\circ} \mathrm{C}$ ) and in period II, $16.3{ }^{\circ} \mathrm{C}$ (range from $14.3^{\circ} \mathrm{C}$ to $18.0^{\circ} \mathrm{C}$ ).

\subsection{Drought Indices}

\subsubsection{Palmer Drought Severity Index (PDSI)}

This indicator shows that during approximately half of the months from 1950 to 2015, a drought of varying intensity was present. Severe droughts were recorded in 53 months and extreme drought in 85 months. During period I (1950-1966), the longest intense droughts (PDSI < -3.0) lasted from November 1951 to August 1952, from December 1953 to May 1955 and from January 1964 to January 1967 and in period II (1985-2015) from July 1991 to January 1995. Drought conditions occurred during 
the three months of greatest spruce growth in 1952, from 1954 to 1956 and from 1964 to 1966 in period I and from 1990 to 1995 and from 2001 to 2003 in period II (Figure 4).

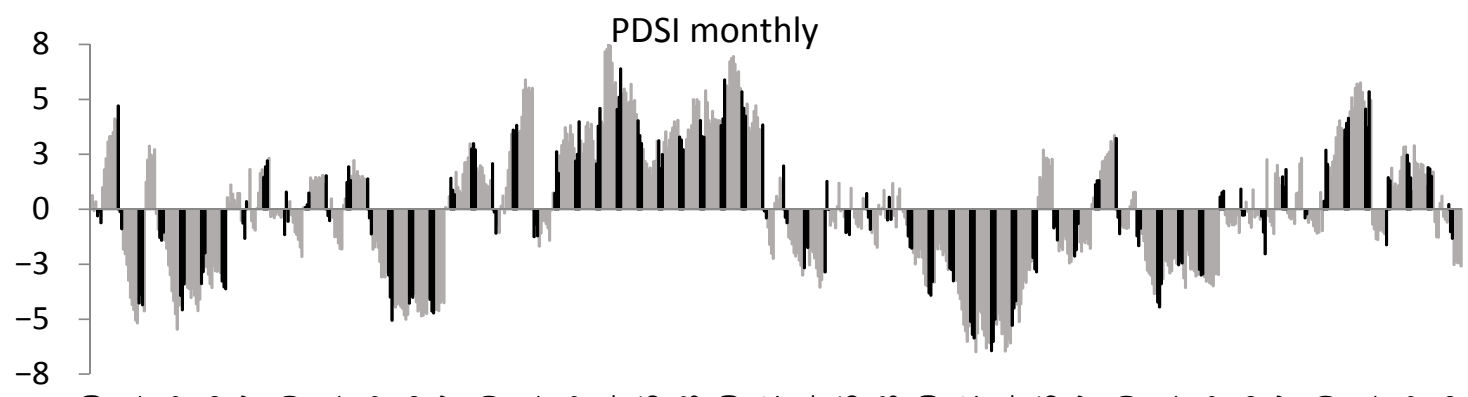

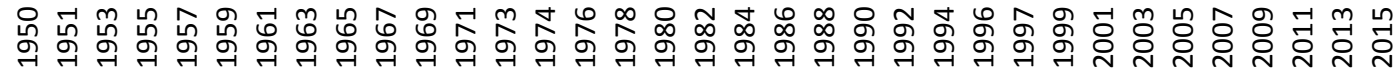
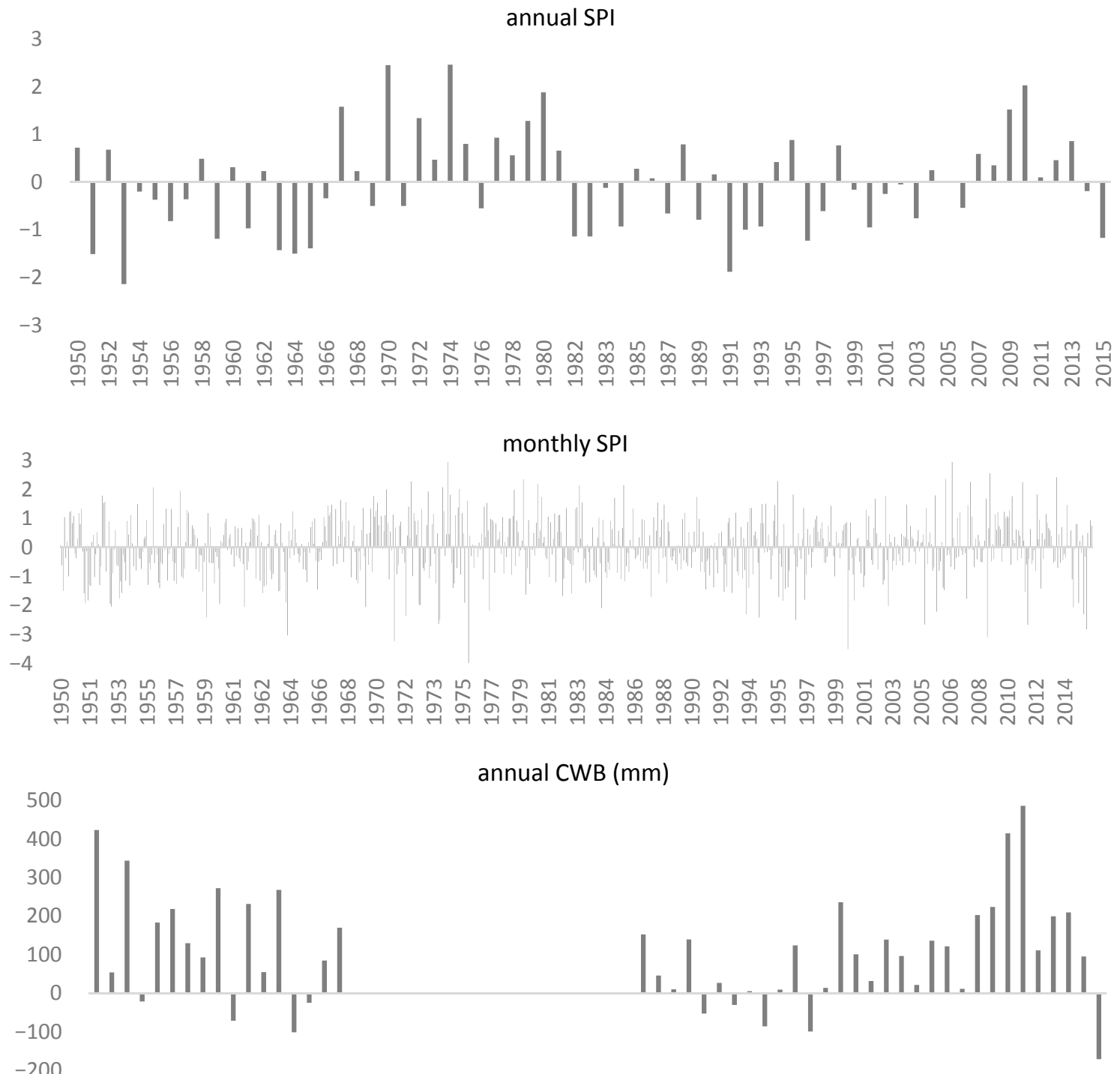

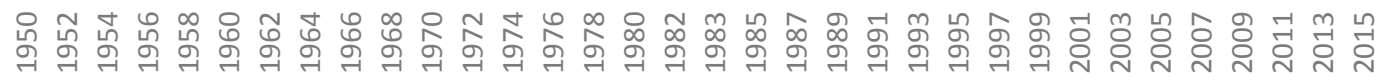

Figure 4. Cont. 


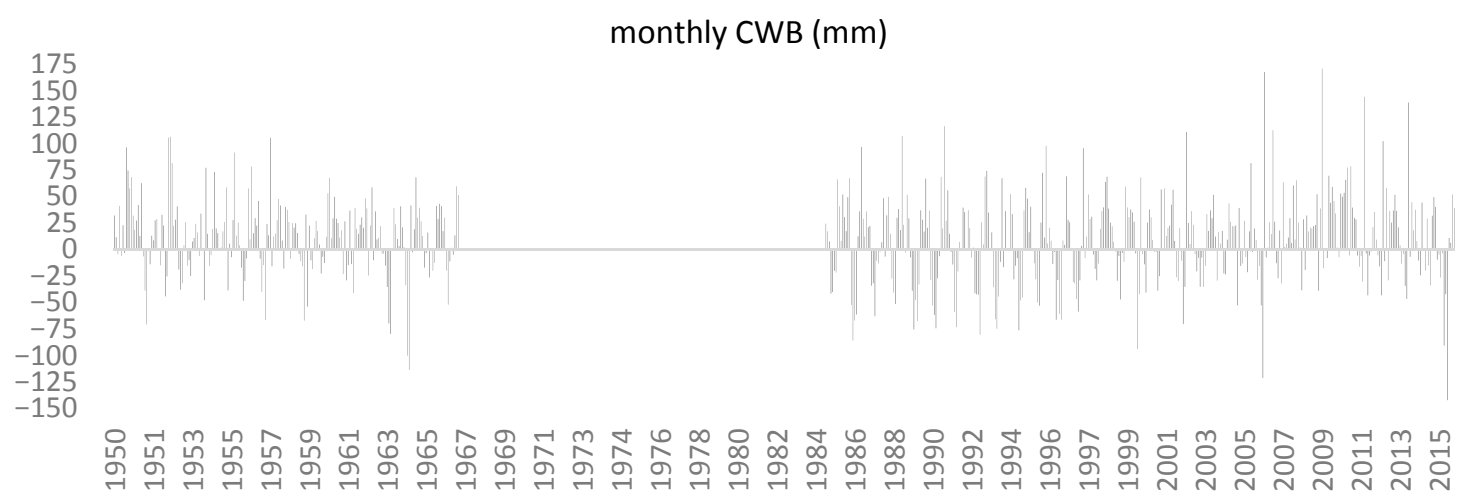

Number of days SWS Deficit

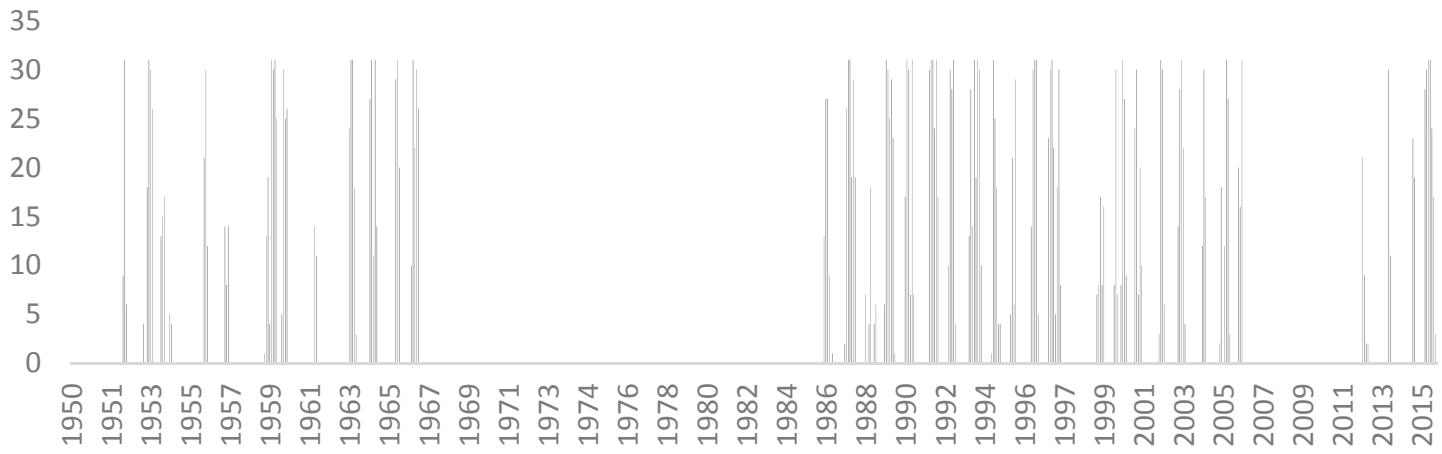

Figure 4. Drought indices from 1950 to 2015 in Bialowieza. PDSI-Palmer Drought Severity Index, SPI-Standardized Precipitation Index, CWB-Climatic Water Balance, SWS—soil water storage.

\subsubsection{Standardized Precipitation Index (SPI)}

During period I, extreme drought occurred in 1953 and severe drought in 1951 and 1962. During period II, severe drought occurred only in 1991. The SPI during this period does not indicate the occurrence of extreme drought. Monthly SPI values reached levels of -3.99 to 2.95. However, the high variability in monthly rainfall translates into a high variability in the SPI index and, therefore, it is not possible to distinguish clear trends or homogeneous periods with these values. Even during the wet years of 1966-1982, monthly SPIs indicated the occurrence of extreme drought (July 1969, May 1971, February 1972, March and April 1974, February 1976, June 1977) and severe drought (December 1972, January 1973, November 1975, October 1979, November, February and November 1982) (Figure 4).

The SPI indicated the occurrence of intense drought (SPI <-1.5) during the months of greatest spruce growth in July 1951, May 1959 and June and July 1964 during period I and in June 1962, May 2000 and June 2015 during period II (Figure 4).

\subsubsection{Climatic Water Balance (CWB)}

The annual CWB calculated for the two periods showed a water deficit in 1953, 1959, 1963, 1964 (period I) and 1989, 1991, 1993, 1996 and 2015 (period II). During period I, 71 months had negative CWBs and during period II 161. The highest water deficits (CWB $<-50 \mathrm{~mm}$ ) during period I occurred from May to August and of the 17 individual months of this period, they occurred during $6 \%$ of the months of May, $18 \%$ of June, $18 \%$ of July and $12 \%$ of August. During period II, a water deficit of greater than $50 \mathrm{~mm}$ was recorded from April to August over 31 years and it occurred during 10\% of the months of April, 22\% of May, 32\% of June, 19\% of July and 13\% of August (Figure 4). 


\subsubsection{Soil Water Storage Deficit (SWS at SWP $\geq-1.5 \mathrm{MPa}$ )}

A limited availability of soil water during period I occurred in 51 months and during period II in 125 months. Soil water content in the root zone of spruce were not limited only in 1950, 1951, 1955, 1958 and 1962 during period I and in 1985, 1998, 2007, 2008, 2009, 2010 and 2011 during period II. During period I, spruce was threatened by a lack of soil water during the months of its greatest growth only in 1959. This situation occurred in 14 years during period II (Figure 4).

\subsubsection{Droughts Indicated by at Least Two Indices}

The occurrence of drought during both periods had a similar frequency. From 1950 to 1966, summer drought was indicated by at least two drought indices over 8 years (a total of 14 months during the spruce growth periods). In 1954, drought occurred during all 3 months (May-July) of spruce growth. All the calculated indicators indicate the presence of drought in June and July 1964 (Table 2). From 1985 to 2015, at least two indicators showed the occurrence of summer drought for 16 years (a total of 32 months during the period of spruce growth). Drought during all months of spruce growth (May, June and July) occurred in 1986, 1990, 1992 and 1993 (Table 2).

Table 2. Periods of drought indicated by at least two indices during the months of spruce growth during periods I and II.

\begin{tabular}{|c|c|c|c|c|c|c|c|c|c|c|c|}
\hline \multicolumn{5}{|c|}{ I Period } & \multicolumn{7}{|c|}{ II Period } \\
\hline Year & Month & SPI & PDSI & CWB & SWSDef. & Year & Month & SPI & PDSI & CWB & SWSDef. \\
\hline 1952 & VII & & $*$ & & * & 1986 & $\mathrm{~V}$ & & & * & $*$ \\
\hline 1954 & $\mathrm{~V}$ & & * & & * & 1986 & VI & & & * & * \\
\hline 1954 & VI & & * & & * & 1986 & VII & & & * & * \\
\hline 1954 & VII & & * & & * & 1987 & VI & & & * & * \\
\hline 1956 & VI & & * & & * & 1989 & $\mathrm{~V}$ & & & * & * \\
\hline 1956 & VII & & * & & * & 1989 & VII & & & * & * \\
\hline 1957 & VI & & & * & * & 1990 & $\mathrm{~V}$ & & * & * & * \\
\hline 1959 & $\mathrm{~V}$ & * & & * & * & 1990 & VI & & * & * & * \\
\hline 1959 & VII & & & $*$ & * & 1990 & VII & & * & & * \\
\hline 1963 & VII & & & * & * & 1991 & VI & & & * & * \\
\hline 1964 & VI & * & * & * & * & 1991 & VII & & * & & * \\
\hline 1964 & VII & * & * & * & * & 1992 & $\mathrm{~V}$ & & * & & * \\
\hline 1966 & VI & & * & * & * & 1992 & VI & * & * & & * \\
\hline \multirow[t]{19}{*}{1966} & VII & & $*$ & & * & 1992 & VII & & * & & * \\
\hline & & & & & & 1993 & V & & * & * & * \\
\hline & & & & & & 1993 & VI & & * & * & * \\
\hline & & & & & & 1993 & VII & & * & & * \\
\hline & & & & & & 1994 & VI & & * & & * \\
\hline & & & & & & 1994 & VII & & * & * & * \\
\hline & & & & & & 1995 & VI & & & * & * \\
\hline & & & & & & 1995 & VII & & & * & * \\
\hline & & & & & & 1996 & $\mathrm{~V}$ & & & * & * \\
\hline & & & & & & 1996 & VII & & & * & * \\
\hline & & & & & & 1997 & VI & & & * & * \\
\hline & & & & & & 2000 & $\mathrm{~V}$ & $*$ & & $*$ & * \\
\hline & & & & & & 2001 & $\mathrm{~V}$ & & $*$ & & * \\
\hline & & & & & & 2001 & VI & & * & & * \\
\hline & & & & & & 2001 & VII & & $*$ & & $*$ \\
\hline & & & & & & 2003 & VI & & * & & * \\
\hline & & & & & & 2006 & VI & & & $*$ & * \\
\hline & & & & & & 2006 & VII & & $*$ & $*$ & $*$ \\
\hline & & & & & & 2015 & VI & $*$ & & * & * \\
\hline
\end{tabular}

*—occurrence of drought. 


\subsection{Volume of Wood Cut}

From 2002 to 2017, 211,800 $\mathrm{m}^{3}$ of spruce wood was cut in sanitation felling in the Bialowieza Forest District, which accounted for $95 \%$ of sanitary felling of all tree species, $85 \%$ of total spruce logging and $61 \%$ of all tree species logging (Table 3). The largest amount of timber was cut in 2017-38.1 thousand $\mathrm{m}^{3}$. The least in 2016-5.2 thousand $\mathrm{m}^{3}$ (Table 3). In the whole period, spruce accounted for more than $83 \%$ of harvested wood volume in sanitary cuts, reaching $97 \%$ in 2016 and 2017 (Table 3). Percentage of spruce sanitary felling in total harvest of all species ranged from $22.4 \%$ (2012) to $93.1 \%$ (2017). At the beginning (2002-2004) and end (2014-2017) of the analysed period, sanitary cuts of spruce accounted for more than $60 \%$ of the total cuts for all species (Table 3).

Figure 5 shows the relationship between volume of cut spruce wood in 1 and 2 years after drought and the intensity of drought expressed in drought indices. In the case of each drought indices, there was no relation on the volume of cut spruce wood both in the 1st and 2nd year after the drought $(p>0.05)$. The volume of timber cut after years without drought was at a similar level as in the years after the drought.

Table 3. Total and sanitary logging of wood in Bialowieza Forest District in 2002-2017.

\begin{tabular}{|c|c|c|c|c|c|c|c|c|}
\hline \multirow{3}{*}{ Year } & \multicolumn{3}{|c|}{ Norway Spruce } & \multicolumn{3}{|c|}{ Other Species } & \multicolumn{2}{|c|}{ Percentage of Spruce } \\
\hline & \multirow{2}{*}{$\begin{array}{c}\text { Sanitary } \\
\text { Felling }\left(\mathrm{m}^{3}\right)\end{array}$} & \multirow{2}{*}{$\begin{array}{c}\text { Total } \\
\text { Cutting }\left(\mathrm{m}^{3}\right)\end{array}$} & \multirow[b]{2}{*}{$\%$} & \multirow{2}{*}{$\begin{array}{c}\text { Sanitary } \\
\text { Felling }\left(\mathbf{m}^{3}\right)\end{array}$} & \multirow{2}{*}{$\begin{array}{c}\text { Total } \\
\text { Cutting }\left(\mathrm{m}^{3}\right)\end{array}$} & \multirow[b]{2}{*}{$\%$} & $\begin{array}{l}\text { Sanitary } \\
\text { Felling }\end{array}$ & $\begin{array}{l}\text { Sanitary } \\
\text { Felling }\end{array}$ \\
\hline & & & & & & & $\begin{array}{c}\text { In Sanitary } \\
\text { Felling All } \\
\text { Species }\end{array}$ & $\begin{array}{c}\text { In Total } \\
\text { Cutting All } \\
\text { Species }\end{array}$ \\
\hline 2002 & 21,805 & 22,819 & 95.6 & 1006 & 9643 & 10.4 & 95.6 & 67.2 \\
\hline 2003 & 33,454 & 34,125 & 98 & 630 & 5941 & 10.6 & 98.2 & 83.5 \\
\hline 2004 & 21,098 & 22,536 & 93.6 & 193 & 5162 & 3.7 & 99.1 & 76.2 \\
\hline 2005 & 10,830 & 12,977 & 83.5 & 768 & 10,282 & 7.5 & 93.4 & 46.6 \\
\hline 2006 & 6503 & 9486 & 68.6 & 881 & 9117 & 9.7 & 88.1 & 35.0 \\
\hline 2007 & 12,496 & 15,394 & 81.2 & 1125 & 9366 & 12 & 91.7 & 50.5 \\
\hline 2008 & 13,490 & 16,645 & 81.0 & 804 & 8388 & 9.6 & 94.4 & 53.9 \\
\hline 2009 & 8838 & 13,890 & 63.6 & 898 & 10,297 & 8.7 & 90.8 & 36.5 \\
\hline 2010 & 4282 & 8152 & 52.5 & 547 & 9112 & 6.0 & 88.7 & 24.8 \\
\hline 2011 & 3296 & 6040 & 54.6 & 490 & 5172 & 9.5 & 87.0 & 29.4 \\
\hline 2012 & 2399 & 5883 & 40.8 & 459 & 4808 & 9.6 & 83.9 & 22.4 \\
\hline 2013 & 6194 & 9036 & 68.5 & 414 & 5396 & 7.7 & 93.7 & 42.9 \\
\hline 2014 & 10,004 & 11,467 & 87.2 & 532 & 3778 & 14.1 & 94.9 & 65.6 \\
\hline 2015 & 16,755 & 17,769 & 94.3 & 953 & 3722 & 25.6 & 94.6 & 78.0 \\
\hline 2016 & 4838 & 4996 & 96.8 & 179 & 262 & 68.2 & 96.4 & 92.0 \\
\hline 2017 & 35,522 & 36,617 & 97 & 459 & 1517 & 30.3 & 98.7 & 93.1 \\
\hline sum & 211,804 & 247,832 & & 10,337 & 101,964 & & & \\
\hline mean & 13,238 & 15,489 & 85.5 & 646.1 & 6372.7 & 10.1 & 95.3 & 60.6 \\
\hline
\end{tabular}


1 year after drought
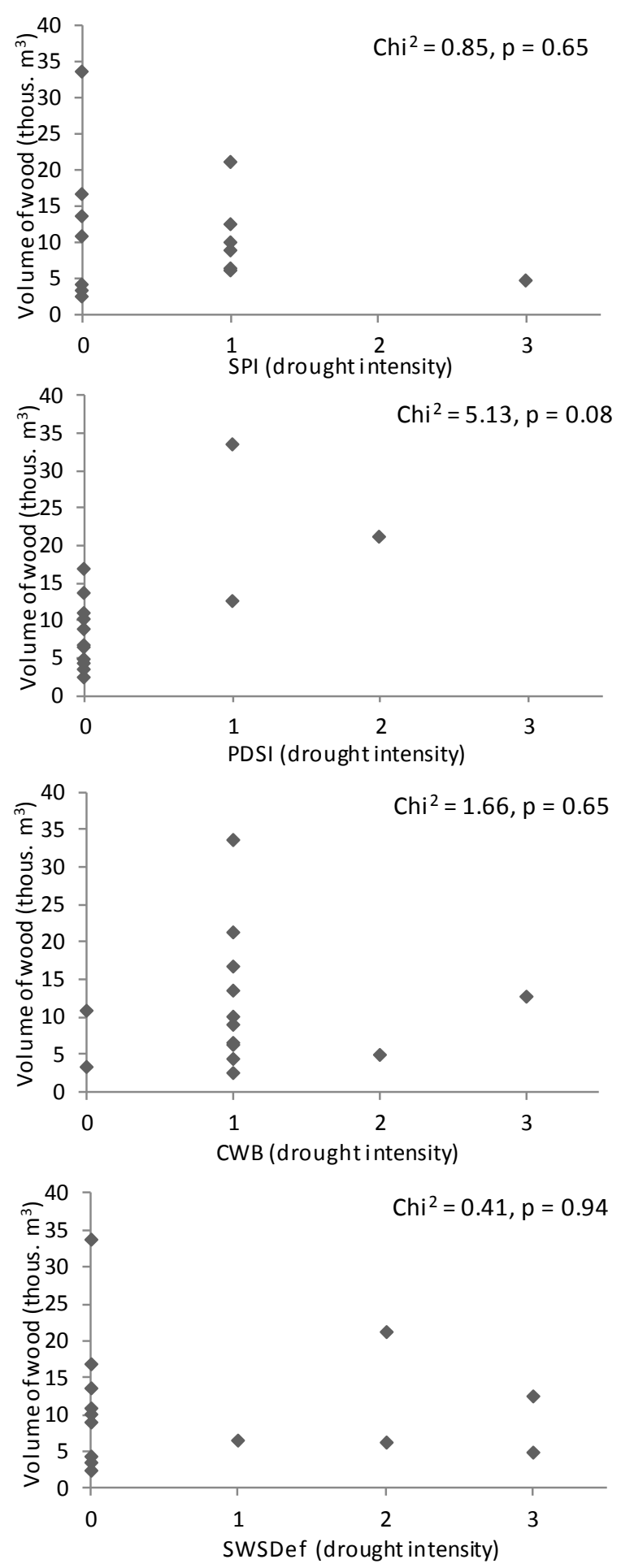

2 year after drought
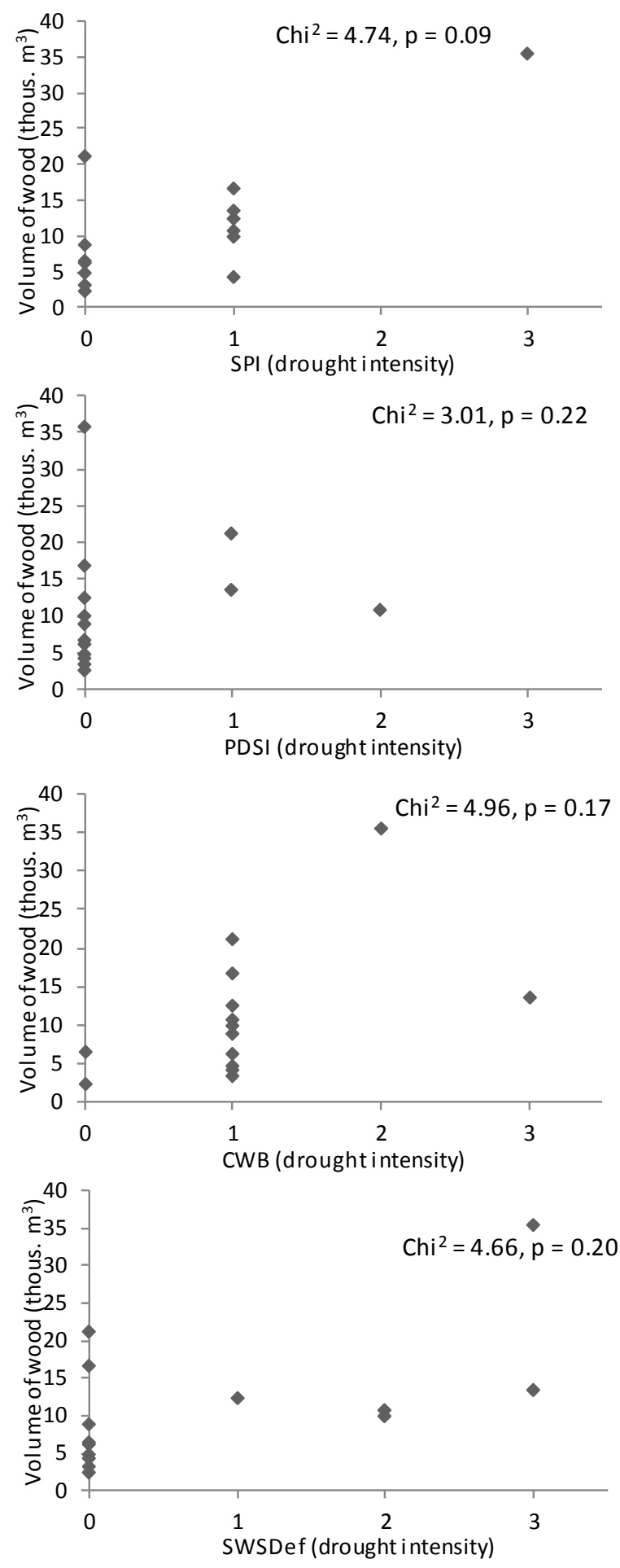

Figure 5. Relationship between drought indices (0-no drought, 1-moderate drought, 2-severe drought, 3-extreme drought) and volume of spruce wood cut in the 1st and 2nd year after drought.

\section{Discussion}

In the Bialowieza forest the temperature increase of $1.27^{\circ} \mathrm{C}\left(0.19^{\circ} \mathrm{C}\right.$ per 10 years $)$ was higher than the change measured at global scale. Over the 100-year period from 1906 to 2005, the average global temperature increased by $0.74{ }^{\circ} \mathrm{C}$ [26]. This is similar to the changes occurring in the Northern 
Hemisphere, where the temperature series showed a significant positive linear trend from 1961 to 2005 [27]. This finding is in line with the research of Christiansen et al. [28], which indicates that central Europe is likely to experience an increase in average annual air temperature above the global average. Other central European countries have also observed a higher increase in temperature compared to that of global change. The mean temperature series for the Czech Republic from 1961 to 2005 shows a statistically significant linear trend reaching $0.27^{\circ} \mathrm{C}$ per 10 years [29]. The warming of the climate in Bialowieza from 1950 to 2015 is comparable to the observed climate changes throughout central Europe.

One of the effects of global warming is the increased risk of drought. On a global scale, there has been an increase in the percentage of annual area experiencing drought from 1902 to 2008 [30]. Since 1970, there has been an increase in the intensity, duration and area of drought [31,32]. In central Europe, it is anticipated that such changes will lead to warmer weather and lower rainfall during the vegetation period [33-35].

When calculated for the entire period, the Palmer Drought Severity Index and annual Standardized Precipitation Index indicate a similar periodicity of water conditions, as shown in the analysis of precipitation $[1,18]$, that is, wet weather prevailed from 1967 to 1983 with no drought conditions (Figure 4). However, before and after this period, conditions conducive to the occurrence of drought were present. The lack of drought during the 1970s in eastern Europe was also pointed out by [36].

The Soil Water Storage deficit was the most common indicator of drought, because of the shallow root system of spruce, which can only use water stored in the upper soil layer. During the summer, with high evapotranspiration, the supply of water available for spruce is quickly depleted. In the absence of rainfall, this leads to a deficit of soil water. Lower rainfall in the lowlands, as in the Bialowieza Forest, makes the spruce more vulnerable to drought stress than in mountainous areas. [37] indicated that the lowest sites (below $500 \mathrm{~m}$ ) are already near the moisture limit of Norway spruce distribution and thus especially sensitive to future drought events.

Norway spruce is well adapted to the cool climate. The warming of the climate and increasing frequency and severity of drought events in Europe are stress factors for the spruce, they cause a decrease in the growth [8] and increase in tree mortality [12]. Dendrochronological research conducted in the Alps shows that Norway spruce and Europe larch are more threatened by the effects of drought than are Scots pine, Black pine and Douglas-fir [38]. America and central Europe indicate the influence of climate warming on the occurrence of spruce bark beetle outbreaks. An unprecedented outbreak of spruce bark beetles in North America and Canada was attributed to a notable increase in summer temperatures during the late 20th century [39]. Kölling et al. [40] suggested that long-lasting temperature increases may be of greater importance for bark beetle infestations in German stands of Norway spruce than singular heat waves. Warm temperatures can reduce overwintering bark beetles' mortality and shorten generation times and severe drought and warm temperatures impose physiological stresses on trees that can impede their defence systems [41]. Warm spring and summer temperatures support an earlier completion of the first filial generation and the establishment of sister and successive generation broods [42]. Seidl et al. [6] and Hlásny and Turčáni [43] showed an increase in insect infestations under conditions of climate warming.

Mass dieback of spruce caused by bark beetle gradation occurred in Bialowieza Forest in 1921-1922. It was attributed to the mass harvesting of trees during World War I and to droughts in 1919-1921. Over 1.3 million $\mathrm{m}^{3}$ of spruce died in the entire Forest (130,000 ha), of that over 300 thousand $\mathrm{m}^{3}$ was removed. A downturn in the gradation was possible due to removal of dead and infested trees, deployment of woodworm traps, expansion of parasitoides and natural enemies and due to favourable meteorological conditions, mainly the long winter that delayed the development of bark beetle generations and their number [44].

Despite such huge losses in spruce stands, the species remained common in BF. Paczoski [45] reported that spruce occurs in all forest stands of the Bialowieza Forest from extremely dry to swampy ones. Until the end of the 20th century, there were no major problems with the health of spruce 
in BF. The phytosociological studies in the second half of the twentieth century demonstrate good condition of spruce stands in the BNP [46]. By the end of the 20th century, old spruce trees were numerous at plots in seven different plant communities [46]. The outbreaks of bark beetle occurred but were of lesser intensity. Problems with the health of spruce have intensified in the 21st century. Due to the warming of the climate, favourable meteorological conditions able to confine the development and the number of bark beetle generations are less probable than at the beginning of the 20th century. According to the studies by Hanewinkel et al., [10] Norway spruce shifts northward and probably loses large parts of the central, eastern and western Europe. It is anticipated that the spruce will diminish its importance for the ecosystems of the Bialowieza Forest and for forest management. The proposed natural renewal of spruce [47] will pose a further threat for the successful spruce forest restoration. Decreasing number of old spruce seed trees, wildlife pressure, competition from expansive tree species such as hornbeam will hamper successful natural regeneration of spruce in Bialowieza Forest.

During the outbreak periods, the volume of the removed wood from spruce-beetle infected trees was as follows: during the years 1958-1963-7.5 thousand $\mathrm{m}^{3}, 1963-1966-27$ thousand $\mathrm{m}^{3}$, 1994-1996-64 thousand $\mathrm{m}^{3}$ and 2000-2002-approximately 80 thousand $\mathrm{m}^{3}$ [48]. On transitional peatlands with Norway spruce stands (Sphagno girgensohnii-Piceetum Polak. 1962), the tree layer cover was equal to $65.6 \%$ during the 1970 s but only $46.8 \%$ from 2003 to 2005 [49] The volume of dead spruce tree trunks during this period in the BNP Strict Reserve stands was $81,000 \mathrm{~m}^{3}$ [50]. From 2012 to 2015, the mortality of spruces in the BNP was less than that in the managed stands or nature reserves of the Bialowieza Forest. This finding could be explained by the fact that in the BNP Strict Reserve, a significant portion of the trees susceptible to spruce bark beetle feeding were killed during the earlier infestation of 2000-2004 [51]. From 2012 to 2016, more than one million $\mathrm{m}^{3}$ of spruce deadwood were recorded in the managed forests as a result of the activity of bark beetles [5]. However, no clear relationship was found between the occurrence of droughts and the volume of wood cut in sanitary cuts in the Bialowieza Forest District in the years 2002-2015. This could be due to the fact that the volume of cut spruce wood was very large and in some years accounted for over $90 \%$ of the wood of all tree species. This shows that the decline of spruce is so intense that the drought as an initiating factor has ceased to be of decisive importance.

A recognized method of limiting the number of bark beetle is cutting trees affected with bark beetles in sanitary felling. Higher sanitation felling intensity decreases the number of infestation trees in the following year [52]. But sanitation felling is only effective when carried out in time, that is, before the beetles have emerged [53]. In 1998, the possibility of cutting trees over 100 years old was limited in the Bialowieza Forest. It also concerned spruces infested with bark beetles. The long-term procedure for obtaining a cut-out permit meant that the principle of removal of infected trees in a timely manner could not be met. Therefore, limiting the number of bark beetle in sanitary felling could not be effective in the Bialowieza Forest after 1998.

\section{Conclusions}

From 1950 to 2015, Bialowieza Forest experienced climate warming comparable to changes observed throughout the Northern Hemisphere. Droughts occurred both in the 1950s and 1960s, as well as after 1985. However, a mass dieback of spruce has occurred in recent years. This shows that drought alone is not a factor leading to spruce dieback. Spruce, as a species with a shallow root system, may be highly resistant to the lack of available water. However, the combined occurrence of drought with global warming may be the decisive factor in the dieback of spruce. The alteration of the spruce physiological processes caused by climate warming, as well as an increase of bark beetle activity may, together with drought and limitation of sanitary felling, be lethal to spruce stands.

Author Contributions: A.B. designed the study, conducted data analyses, wrote the paper; A.K. co-developed the model code (part of interception) and contributed to writing the manuscript; M.K. supported data analysis; K.S. supported data analysis. 
Funding: This research and APC was funded by the Ministry of Science and Higher Education through a Forest Research Institute statutory activity grant number 240125.

Acknowledgments: The authors would like to thank the employees of the Bialowieza Forest District for providing information about the forests.

Conflicts of Interest: The authors declare no conflict of interest.

\section{References}

1. Boczoń, A. Characteristics of thermal and pluvial conditions in the Białowieża Primeval Forest between 1950 and 2003. For. Res. Pap. 2006, 1, 57-72. (In Polish)

2. Boczoń, A. Groundwater in the Bialowieza Primeval Forest in the dry year 2000. Sylwan 2002, 7, 93-105. (In Polish)

3. Boczoń, A.; Kowalska, A.; Dudzińska, M.; Wróbel, M. Drought in Polish Forests in 2015. Pol. J. Environ. Stud. 2016, 25, 1857-1862. [CrossRef]

4. Grodzki, W. Mass outbreaks of the spruce bark beetle Ips typographus in the context of the controversies around the Białowieża Primeval Forest. For. Res. Pap. 2016, 77, 324-331. [CrossRef]

5. Hilszczanski, J.; Starzyk, J.R. Is it possible and necessary to control European spruce bark beetle Ips typographus (L.) outbreak in the Białowieża Forest? For. Res. Pap. 2017, 78, 88-92. [CrossRef]

6. Seidl, R.; Rammer, W.; Jäger, D.; Lexer, M.J. Impact of bark beetle (Ipstypographus L.) disturbance on timber production and carbon sequestration indifferent management strategies under climate change. For. Ecol. Manag. 2008, 256, 209-220. [CrossRef]

7. Zweifel, R.; Rigling, A.; Dobbertin, M. Species-specific stomatal response of trees to drought-A link to vegetation dynamics? J. Veg. Sci. 2009, 20, 442-454. [CrossRef]

8. Lévesque, M.; Saurer, M.; Siegwolf, R.; Eilmann, B.; Brang, P.; Bugmann, H.; Rigling, A. Drought response of five conifer species under contrasting water availability suggests high vulnerability of Norway spruce and European larch. Glob. Chang. Biol. 2013, 19, 3184-3199. [CrossRef] [PubMed]

9. Spinoni, J.; Naumann, G.; Vogt, J.; Barbosa, P. European drought climatologies and trends based on a multi-indicator approach. Glob. Planet. Chang. 2015, 127, 50-57. [CrossRef]

10. Hanewinkel, M.; Cullmann, D.A.; Schelhaas, M.-J.; Nabuurs, G.-J.; Zimmermann, N.E. Climate change may cause severe loss in the economic value of European forest land. Nat. Clim. Chang. 2013, 3, $203-207$. [CrossRef]

11. Allen, C.; Macalady, A.; Chenchouni, H.; Bachelet, D.; McDowell, N.; Vennetier, M.; Kitzberger, T.; Rigling, A.; Breshears, D.; Hogg, E.; et al. A global overview of drought and heat-Induced tree mortality reveals emerging climate change risks for forests. For. Ecol. Manag. 2010, 259, 660-684. [CrossRef]

12. Birdsey, R.; Pan, Y. Ecology: Drought and dead trees. Nat. Clim. Chang. 2011, 1, 444-445. [CrossRef]

13. Stereńczak, K.; Kraszewski, B.; Mielcarek, M.; Piasecka, Z. Inventory of standing dead trees in the surroundings of communication routes-The contribution of remote sensing to potential risk assessments. For. Ecol. Manag. 2017, 402, 76-91. [CrossRef]

14. Salmi, T.; Määttä, A.; Anttila, P.; Ruoho-Airola, T.; Amnell, T. Detecting Trends of Annual Values of Atmospheric Pollutants by the Mann-Kendall Test and Sen's Slope Estimates-The Excel Template Application MAKESENS; Publications on Air Quality. No. 31; Finnish Meteorological Institute: Helsinki, Finland, 2002.

15. McKee, T.B.; Doesken, N.J.; Kleist, J. The relationship of drought frequency and duration to time scales. In Proceedings of the 8th Conference of Applied Climatology, Anaheim, CA, USA, 17-22 January 1993; pp. 179-184.

16. Łabęzki, L. Estimation of local drought frequency in Central Poland using the standardized precipitation index SPI. Irrig. Drain. 2007, 56, 67-77. [CrossRef]

17. Palmer, W.C. Meteorological Drought; Research Paper No. 45; U.S. Weather Bureau: Washington, DC, USA, 1965.

18. Pierzgalski, E.; Boczoń, A.; Tyszka, J. Variability of precipitation and groundwater table in the Białowieża National Park. Kosmos Probl. Nauk Biol. 2002, 4, 415-425. (In Polish)

19. Wendling, U.; Muller, J. Entwicklung eines Verfahrens zur rechnerischen Abschatzung der Verdunstung im Winter (Treatise of a method for numerical estimation of the evapotranspiration in winter). Z. Meteorol. 1984, 34, 82-85. 
20. Liu, S. A new model for the prediction of rainfall interception in forest canopies. Ecol. Model. 1997, 99, 151-159. [CrossRef]

21. Liu, S. Evaluation of the Liu model for predicting rainfall interception in forests world-wide. Hydrol. Process. 2001, 15, 2341-2360. [CrossRef]

22. Kondo, J.; Nakazono, M.; Watanabe, T. Hydrological climate in Japan (2): Forest rainfall interception. J. Jpn. Soc. Hydrol. Water Resour. 1992, 5, 29-36, (In Japanese with English Summary). [CrossRef]

23. Komatsu, H.; Shinohara, Y.; Kume, T.; Otsuki, K. Relationship between annual rainfall and interception ratio for forests across Japan. J. Hydrol. 2008, 256, 1189-1197. [CrossRef]

24. Ostonen, I.; Lohmus, K.; Pajuste, K. Fine root biomass, production and its proportion of NPP in a fertile middle-aged Norway spruce forest: Comparison of soil core and ingrowth core methods. For. Ecol. Manag. 2005, 212, 264-277. [CrossRef]

25. R Core Team. R: A Language and Environment for Statistical Computing; R Foundation for Statistical Computing: Vienna, Austria, 2017; Available online: https:/ / www.R-project.org/ (accessed on 13 February 2018).

26. Solomon, S.; Qin, D.; Manning, M.; Marquis, M.; Averyt, K.; Tignor, M.M.B.; LeRoy Miller, H.; Chen, Z. Climate Change 2007: The Physical Science Basis; Cambridge University Press: Cambridge, UK; New York, NY, USA, 2007.

27. Brohan, P.; Kennedy, J.J.; Haris, I.; Tett, S.F.B.; Jones, P.D. Uncertainty estimates in regional and global observed temperature changes: A new dataset from 1850. J. Geophys. Res. 2006, 111, D12106. [CrossRef]

28. Christensen, J.H.; Hewitson, B.; Busuioc, A.; Chen, A.; Gao, X.; Held, R.; Jones, R.; Kolli, R.K.; Kwon, W.; Laprise, R.; et al. (Eds.) Climate Change, 2007: The Physical Science Basis. Contribution of Working Group I to the Fourth Assessment Report of the Intergovernmental Panel on Climate Change, University Press Cambridge, Chapter 11; Cambridge University Press: Cambridge, UK; New York, NY, USA; pp. 847-940.

29. Brázdil, R.; Chromá, K.; Dobrovolný, P.; Tolasz, R. Climate fluctuations in the Czech Republic during the period 1961-2005. Int. J. Climatol. 2009, 29, 223-242.

30. Wang, Q.; Wu, J.; Lei, T.; He, B.; Wu, Z.; Liu, M.; Mo, X.; Geng, G.; Li, X.; Zhou, H.; et al. Temporal-spatial characteristics of severe drought events and their impact on agriculture on a global scale. Quat. Int. 2014, 349, 10-21. [CrossRef]

31. Blunden, J.; Arndt, D.; Baringer, M. State of the Climate in 2010. Bull. Am. Meteorol. Soc. 2011, 92, S1-S236. [CrossRef]

32. Burke, E.J.; Brown, S.J.; Christidis, N. Modeling the recent evolution of global drought and projections for the twenty-first century with the Hadley Centre climate model. J. Hydrometeorol. 2006, 7, 1113-1125. [CrossRef]

33. Briffa, K.R.; van der Schrier, G.; Jones, P.D. Wet and dry summers in Europe since 1750: Evidence of increasing drought. Int. J. Climatol. 2009, 29, 1894-1905. [CrossRef]

34. Degirmendžić, J.; Kożuchowski, K.; Żmudzka, E. Changes of air temperature and precipitation in Poland in the period 1951-2000 and their relationship to atmospheric circulation. Int. J. Climatol. 2004, 24, 291-310. [CrossRef]

35. Dubrovsky, M.; Svoboda, M.D.; Trnka, M.; Hayes, M.J.; Wilhite, D.A.; Zalud, Z.; Hlavinka, P. Application of relative drought indices in assessing climate change impacts on drought conditions in Czechia. Theor. Appl. Climatol. 2009, 96, 155-171. [CrossRef]

36. Spinoni, J.; Naumann, G.; Vogt, J.; Barbosa, P. The biggest drought events in Europe from 1950 to 2012. J. Hydrol. Reg. Stud. 2015, 3, 509-524. [CrossRef]

37. Tumajer, J.; Altman, J.; Štěpánek, P.; Treml, V.; Doležal, J.; Cienciala, E. Increasing moisture limitation of Norway spruce in Central Europe revealed by forward modelling of tree growth in tree-ring network. Agric. For. Meteorol. 2017, 247, 56-64. [CrossRef]

38. Lévesque, M.; Rigling, A.; Bugmann, H.; Weber, P.; Brang, P. Growth response of five co-occurring conifers to drought across a wide climatic gradient in Central Europe. Agric. For. Meteorol. 2014, 197, 1-12. [CrossRef]

39. Berg, E.E.; Henry, J.D.; Fastie, C.L.; de Volder, A.D.; Matsuoka, S.M. Spruce beetle outbreaks on the Kenai Peninsula, Alaska, and Kluane National Park and Reserve, Yukon Territory: Relationship to summer temperatures and regional differences in disturbance regimes. For. Ecol. Manag. 2006, 227, 219-232. [CrossRef]

40. Kölling, C.; Knoke, T.; Schall, P.; Ammer, C. Überlegungen zum Risiko des Fichtenanbaus in Deutschland vor dem Hintergrund des Klimawandels. Forstarchiv 2009, 80, 42-54. 
41. Raffa, K.F.; Aukema, B.H.; Bentz, B.J.; Carroll, A.L.; Hicke, J.A.; Kolb, T.E. Responses of tree-killing bark beetles to a changing climate. In Climate Change and Insect Pests; Bjorkman, C., Niemela, P., Eds.; Centre for Agriculture and Biosciences International (CABI): Wallingford, UK, 2015; pp. 173-201.

42. Wermelinger, B.; Seifert, M. Analysis of the temperature dependent development of the spruce bark beetle Ips typographus (L.) (Col., Scolytidae). J. Appl. Entomol. 1998, 122, 185-191. [CrossRef]

43. Hlásny, T.; Turčáni, M. Insect pests as climate change driven disturbances in forest ecosystems. In Bioclimatology and Natural Hazards; Střelcová, K., Matyas, C., Kleidon, A., Lapin, M., Matejka, F., Blazenec, M., Kvarenina, J., Holecy, J., Eds.; Springer: Dordrecht, The Netherlands, 2009; pp. 165-177.

44. Mokrzecki, Z. Report on the control of bark beetle in the Bialowieza Forest in 1922. Las Polski 1923, 4, $297-307$. (In Polish)

45. Paczoski, J. Bialowieza Forests; Monografie Naukowe 1; Państwowa Rada Ochrony Przyrody: Poznań, Poland, 1930. (In Polish)

46. Sokołowski, A.W. Forests of the Białowieża Forest; Centrum Informacyjne Lasów Państwowych (CILP): Warsaw, Poland, 2004; ISBN 83-88478-44-3. (In Polish).

47. Żmihorski, M.; Chylarecki, P.; Orczewska, A.; Wesołowski, T. Białowieża Forest: A new threat. Science 2018, 361, 238. [CrossRef] [PubMed]

48. Michalski, J.; Starzyk, J.R.; Kolk, A.; Grodzki, W. Threat of Norway spruce caused by the bark beetle Ips typographus (L.) in the stands of the forest promotion complex "Puszcza Białowieska" in 2000-2002. For. Res. Pap. 2004, 3, 5-30.

49. Czerepko, J. A long-term study of successional dynamics in the forest wetlands. For. Ecol. Manag. 2008, 255, 630-642. [CrossRef]

50. Miścicki, S. Structure and dynamics of temperate lowland natural forest in the Białowieża National Park. Pol. For. 2012, 85, 473-483. [CrossRef]

51. Miścicki, S. Changes in the stands of the Białowieża National Park from 2000 to 2015. For. Res. Pap. 2016, 77, 371-379. [CrossRef]

52. Stadelmann, G.; Bugmann, H.; Meier, F.; Wermelinger, B.; Bigler, C. Effects of salvage logging and sanitation felling on bark beetle (Ips typographus L.) infestations. For. Ecol. Manag. 2013, 305, 273-281. [CrossRef]

53. Wermelinger, B.; Epper, C.; Kenis, M.; Ghosh, S.; Holdenrieder, O. Emergence patterns of univoltine and bivoltine Ips typographus (L.) populations and associated natural enemies. J. Appl. Entomol. 2012, 136, 212-224. [CrossRef] 